\title{
Management of a Wild Boar Population and its Effects on Commercial Land
}

\author{
Roman ANDRZEJEWSKI ${ }^{1} \&$ Włodzimierz JEZIERSKI ${ }^{2}$
}

\begin{abstract}
Andrzejewski R. \& Jezierski W., 1978: Management of a wild boar population and its effects on commercial land, Acta theriol., 23, 19: $309-339$ [With 16 Tables \& 6 Figs.]
\end{abstract}

Studies were made from 1965-1970 within the Kampinos National Park forests near Warsaw and surrounding area, for the purpose of ascertaining the possibility of limiting the amount of damage caused by wild boar, Sus scrofa Li n n a u s, 1758 on commercial land. The purpose of managing the population was to bring about a greater number of older individuals. The population was regularly supplied with supplementary food, records were kept of the degree to which use was made of the food, feeding times, along with damage done by the animals to crops. A total of 507 individuals was marked, obtaining 2640 captures and 6180 separate observations. The supply of food brought about an increase in population numbers from about 30 to 250 animals (within an area of approx. 2.5 thousand ha of wooded land), followed by a decrease of about 50-70 individuals. The population consisted of settled and migrating (ephemeral) individuals. Some of the individuals were found to migrate over a considerable distances (over $250 \mathrm{~km}$ ). The number of females in the population exceeded the number of males, particularly in the older age classes. Increase in population numbers resulted in the animals feeding on supplementary food during the daytime hours also. Consumption of supplementary food decreased damages in spite of increasing the population numbers. The wild boar caused $75 \%$ of all damage from May to August. It is suggested that supplementary food should be provided for wild boar during the period when maximum damage is done since, by appropriately controlling age structure, population density can be maintained on a level of $30-40$ animals per 1000 ha of woodland.

[Inst. Ecol., Polish Acad. Sci., Dziekanów Leśny, 05-150 Łomianki, Poland].

Present address: 1 Res. Inst. Environ. Develop., Krzywickiego 9, 02-078 Warszawa. 2 Teacher's Training Coll., Dept. Ecol. \& Environ. Protect., Zołnierska 14, 10-561 Olsztyn, Poland. 
1. Introduction

2. Study area

3. Methods and material

4. Density and population structure

4.1. Estimating numbers of individuals in the study area . . . . . 314

4.2. Reproduction and population age structure . . . . . . . . . . . . 316

4.3. Migration of animals . . . . . . . . . . . . . . . . . . . . . . $\quad . \quad 318$

4.4. Variations in numbers . . . . . . . . . . . . . . . . . . . . 324

5. Feeding activities of the population and extent of damage done in agricultural land

5.1. Daily feeding activity rhythm and annual feeding cycle

5.2. Amount of damage caused by the study population in agricultural land

6. Discussion

References

\section{INTRODUCTION}

The problem of damage caused by game animals on field crops and meadows has attracted the attention of a large number of researchers for a considerable time (Dombrowski, 1896; Sylva-Tarouca, 1900; Rör ig, 1912; E c k, 1929; L incke, 1938; B ob a ck, 1957; H aber, 1962; Andrzejewski \& Jezierski, 1969; Jezierski, 1972 and many others). Attention was paid, inter alia, to the fact that such damage is economically undesirable because of the considerable losses caused to agricultural production. On this account it has been suggested that the numbers of large game animals, particularly the wild boar (Sus scrofa Linna e us, 1758), should be greatly limited. This postulate has in turn aroused protest from those who have pointed out the important role played by wild boar in forest biocenoses. In particular this applies to large areas of pine monocultures in poor habitats ( $\mathrm{K}$ o e $\mathrm{h}$ le r, 1954; M r oz ow ski, 1966; H a be r, 1967; B r i ed e r ma n n, 1968 and others). Principles for reducing the amount of damage done by wild boar in fields, based on theoretical consideration of the relation between the way in which a population uses a habitat and the internal population structure, have been laid down by Andrzejewski \& Jezierski (1969).

The purpose of the present study was to examine the chief parameters of a wild boar population: density, migration, age and sex structure, and, in relation to this, to search by means of experimental supplementary feeding and control of the age structure, for a means of reducing the damage caused by wild boar on cultivated crops.

\section{STUDY AREA}

The studies were made in the wooded areas of the north-eastern part of the Kampinos National Park near Warsaw, and in the fields adjoining it (Fig. 1). The 
study area was bounded on its eastern side by the city of Warsaw, on the south by the escarpment of the river valley of the Vistula, on the west by a belt of dunes covered by woods and on the north by the Vistula mainstream. The study area, consisted of forest area of about 2.500 ha in the Kampinos National Park.

The whole of the wooded part of the study area is situated on the dune terrace of the Vistula, which varies only very slightly in height (from 66 to $103 \mathrm{~m}$ above sea level). Included in this area is a narrow belt of dune sands and an extensive area of marshland interspaced by numerous woods of the Carpinion alliance. The ground water table was everywhere relatively high and directly dependent on precipitation. In marshy land water persisted on the surface of the soil practically throughout the whole year (only extremely dry summers forming an exception to this), whereas in the woods it occurred only just below soil surface (not lower than $150 \mathrm{~cm}$ ). This results, within the forest, in sphagnum peat bogs occurring in depressions and podzolized soils in the woods ( $\mathrm{Traczyk} \& \mathrm{Traczyk}, 1965$; H e y m a n o s ki, 1966).

The type of woods in the study area was defined by the following phytosocioiogical associations: Salici-Franguletum Malc,, 1929, Carici elongatae-Alnetum K o c h, 1926, wet coniferous forest with Politrichum communae, Vaccinio myrtilli-Pinetum molinietosum (K o be ndza, 1930) B r. - B l. e t Vlieg e r, 1939, Vaccinio uliginosi-Pinetum Kle is t, 1929, Tilio-Carpinetum T. Tracz y k, 1962 and Pino-Quercetum $\mathrm{K}$ ozłows ka, 1925. Not quite $3 \%$ of the study area was occupied by uncultivated meadows, with the phytosociological associations typical of these kind of plant communities, primarily Caricetum elatae $\mathrm{Koch}, 1926$ ( Traczyk \& Traczyk, 1963).

Climatic conditions in the study area were characterized by very low mean annual precipitation (about $500 \mathrm{~mm}$ ), 60 days with snow cover, mean January temperature $-2.6^{\circ} \mathrm{C}$, mean July temperature $18.9^{\circ} \mathrm{C}$ and a growing season with temperatures above $5^{\circ} \mathrm{C}$ including the period from last April to November ( $\mathrm{Er}$ $\mathrm{mi} \mathrm{ch}, 1951)$.

The forest was intensively visited by tourists from nearby Warsaw, with which this area is connected by public transport, hence places in which the wild boar could live undisturbed were relatively limited.

The forest was thus a relatively good food source for wild boar but less favourable to these animals as a place in which to shelter. There were few buildings in the field area and what groups of buildings there were, were scattered (in addition to a certain number of villages there were numerous individual dwellings). As a large amount of potatoes and oats are grown there the area was very attractive as a source of food to wild boar.

\section{METHODS AND MATERIAL}

Study methods consisted of five basic elements: (1). Wild boar caught in corrals $20 \mathrm{~m}$ in diameter surrounded by wooden fencing $2 \mathrm{~m}$ high. The lower part of the fence was reinforced with wire netting up to a height of about $80 \mathrm{~cm}$ from the ground, and sunk about $30 \mathrm{~cm}$ into the ground, to prevent the young animals from escaping the corral between the fence-posts or by rooting underneath. Two (or one only) electromagnetically operated gates gave admittance to the corral, each measuring $3 \mathrm{~m}$ wide, which slid down to close the corral; they could be operated either by the observer sitting in the observation turret or by the wild boar themselves by means of an oscillator closing the electric circuit. This oscillator was located 
in the feeding trough and was therefore moved when the animals were feeding. In addition the corral was equipped with a capture run (a narrowing corridor divided by movable gates into three parts). This made it possible to immobilize the animal or to transfer it to a cage for weighing or transport. The wild boar were attracted into the corral by food which they readily eat, primarily oats and maize.

The captured animals were marked with numbered ear clips, while wild boar over one year old, that is, animals which had left their mothers, were also, marked by coloured tags of different shape making it possible to identify individuals at a distance. Age and sex were recorded for all the wild boar caught, and their weight take at each capture. An individual capture card was made out for each animal at every capture, along with information about all individuals in the company of which the wild boar was caught. The ways in which such records can be used, and the advantages derived from them, have been discussed in detail by Andrzeje w s k i (1969).

(2). Direct observations from an observation turret were used for obtaining more detailed information on sex and age structure of the population, particularly in relation to wild boar which were rarely caught, and also on intra- and interherd relations. Observations were made once a week, beginning before sunset and ending after midnight, that is, during the period of the wild boar's greatest feeding activity. The observation turret consisted of an acoustically insulated closed cabin, heated in winter, placed at a height of several metres (depending on the range of possible observation) fitted with a window giving a panoramic range of observation. Searchlights, fitted on the outside of the cabin, were turned on automatically by a photo-chamber and lit up the observation area from dusk to dawn. This resulted in the wild boar becoming accustomed to light and to making no changes in their behaviour within its range. The feeding site was situated at a distance of about $15 \mathrm{~m}$ from the turret. Some of the turrets were erected near corrals for catching wild boar, but others were placed elsewhere. It was possible to observe the animals entering the corral, and also the gate sliding down, from the turrets near tine corrals.

Observations were made using a $7 \times 50$ field glass, recording inter alia the numbers of the marked animals and also the number, age and sex of unmarked wild boar. (Observations of the behaviour of these animals will form the subject of a separate paper). Observations were made simultaneously on all observation sites and reports kept centrally in the laboratory with which the observers in the turrets were connected by telephone or radio-telephone. This made it possible to carry out continuous observations (without pausing to write down results), current comparison of results of observations from different turrets, direction by the person in charge of the observation action in the laboratory, of the attention of observers to the relevant details, and also current correction of any possible mistakes made by observers in reading off numbers according to tabs etc. An analogical card was made out for animals identified during observations as had been done in the case of captures.

(3). Control of age structure for the purpose of increasing the participation in the wild boar population of the older age classes was carried out in 1967, 1968 and 1969 by reducing a certain number of the animals, in principle animals up to one year old. This was done by catching individually chosen weak individuals and eliminating them.

(4). Continuous recording of the feeding activities of wild boar and the amount 
of food they consumed was achieved by use of special feeding devices consisting of a container and two troughs $2 \mathrm{~m}$ long. Oats were supplied ad libitum and were tipped automatically from the container into the troughs as the food was consumed. An oscillator placed in the troughs, moved by the wild boar as they fed, closed the circuit each time it was moved and transferred impulses to a Jaquet type electropolygraph situated in the laboratory. Recordings were obtained in this way illustrating the time at which the wild boar fed on the given feeding site. The graduated food container gave an accurate record of daily food consumption.

(5). An estimate was made of the amount of damage done by wild boar in fields and the annual cycle of its occurrence on the basis of estimates of damage drawn up for payment of compensation. As these estimates were drawn up jointly by the injured parties and the institute paying compensation, they may be considered very accurate. The species of crop destroyed, extent of destruction with accuracy to one acre and the day on which damage was caused were all recorded from each estimate.

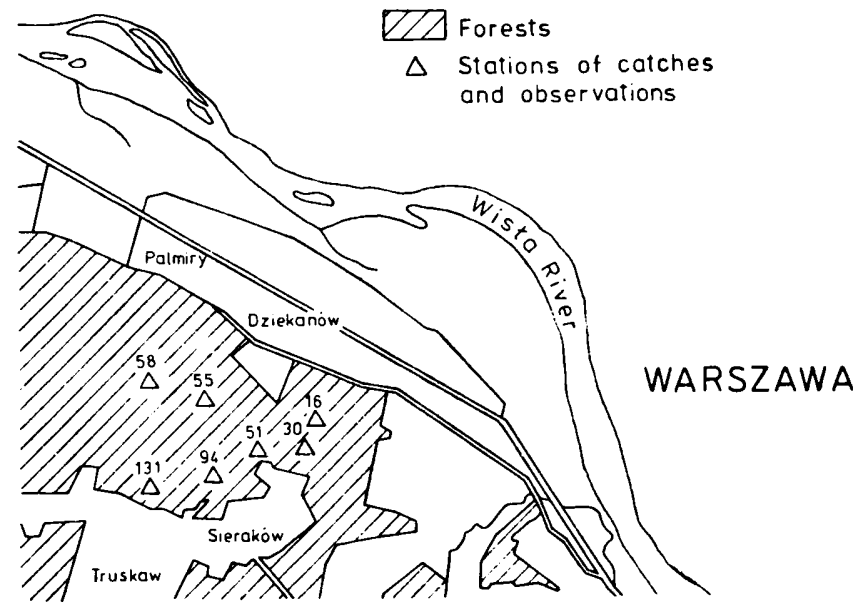

Fig. 1. Plan of study area.

Seven corrals and seven observations sites were situated in the wooded part of the study area (Fig. 1). The studies were made from the autumn of 1965 to the end of 1970, 1966 being treated as the initial year and 1970 the final year, in neither of which were regular observations made.

During the whole study period a total of 507 inidividuals were marked, 2640 captures and 6180 observations were made of the different individuals (Table 1). By comparing these data with the numbers of wild boar in different years (Table 2) it was calculated that each wild boar during the whole period of its stay in the study area was caught approximately 4 times (4.27) and was observed slightly more than 13 times (13.14) from the turrets. Thus on an average one wild boar was recorded 17 times, and over the course of a year more frequently than three times (3.48). The total number of animals caught and marked with ear tabs are shown in Table 3. 
Table 1

Number of captures and observations in different study years.

\begin{tabular}{crc}
\hline Study year & \multicolumn{2}{c}{ Number of: } \\
& Captures & Observations \\
\hline 1966 & 165 & - \\
1967 & 722 & 516 \\
1968 & 1005 & 4023 \\
1969 & 519 & 1641 \\
1970 & 229 & - \\
Total & 2640 & 6180 \\
\hline
\end{tabular}

Table 2

Average number of wild boar living in the study area in different years.

\begin{tabular}{|c|c|c|c|c|c|c|c|c|c|c|}
\hline \multicolumn{4}{|c|}{$\begin{array}{c}\text { Before study } \\
\text { period * }\end{array}$} & \multicolumn{5}{|c|}{ Study period } & \multicolumn{2}{|c|}{$\begin{array}{l}\text { After study } \\
\text { period } * *\end{array}$} \\
\hline & 1963 & 1964 & 1965 & $\overline{1966}$ & 1967 & 1968 & 1969 & $\overline{1970}$ & $\overline{1971}$ & 1972 \\
\hline $\mathrm{N}$ & 34 & 30 & 30 & 54 & 99 & 207 & 163 & 78 & 62 & 51 \\
\hline
\end{tabular}

* Data obtained from the management of the Kampinos National Park.

** After Jezierski \& M y cha, 1975.

Table 3

Total number of wild boar caught and marked with ear-tags.

\begin{tabular}{cccccccc}
\hline $\begin{array}{c}\text { Found } \\
\text { in the } \\
\text { study area }\end{array}$ & \multicolumn{2}{c}{ Entering and settling in the study area in year: } & Total \\
\hline 23 & 1966 & 1967 & 1968 & 1969 & 1970 & \\
\hline & 61 & 102 & 194 & 83 & 44 & 507 \\
\hline
\end{tabular}

During the study period devices for recording feeding activity on all the feeding sites were in operation for a total of 127,488 hours and during this time each feeding was recorded. Inspection was made in the field area from 1963-1970 of 416 ha of damaged agricultural crops and destruction was found on a joint area (total destruction) of 116.46 ha.

\section{DENSITY AND POPULATION STRUCTURE}

\subsection{Estimating Presence of Individuals in the Study Area}

Estimates of the density and age and sex structure of the study population of wild boar were made by the calendar of captures method (A $\mathrm{ndrzejew} \mathrm{k} \mathrm{i,} \mathrm{1969),} \mathrm{taking} \mathrm{as} \mathrm{basic} \mathrm{information} \mathrm{the} \mathrm{data} \mathrm{obtained}$ from captures and direct observations.

In order to estimate the presence and period of residence of each individual in the study area an approximate idea was obtained of whe- 
ther the different individuals remained in the study area between successive captures or observations. Some difficulty was encountered in this connection as the trappability of wild boar (particularly those over one year old) undoubtedly depends on such factors as abundance or lack of natural food, reproduction period, hunger period and weather conditions. Adult individuals were caught less often during certain periods, due to the corrals being quickly closed by younger (especially the youngest) animals.

The relatively low trappability did not permit the use of the truncated distribution method ( $\mathrm{W}$ i e r $\mathrm{zb}$ ow s k a, 1970), since the zero hypothesis of this method makes it necessary to accept a relatively short interval of time between successive captures. Under the circumstances the method proposed by Andrzejewski was used (1963, 1969), assuming that

Table 4

Distribution of time intervals between successive captures of wild boar over one year old.

\begin{tabular}{|c|c|c|}
\hline $\begin{array}{l}\text { Time between } \\
\text { successive } \\
\text { captures } \\
\text { in months }\end{array}$ & $\begin{array}{l}\text { Number } \\
\text { of time } \\
\text { intervals }\end{array}$ & $\begin{array}{l}\text { Increasing percentage } \\
\text { of number of time } \\
\text { intervals }\end{array}$ \\
\hline 1 & 304 & 52.8 \\
\hline 2 & 89 & 68.3 \\
\hline 3 & 38 & 74.8 \\
\hline 4 & 22 & 78.7 \\
\hline 5 & 31 & 84.0 \\
\hline 6 & 20 & 87.5 \\
\hline 7 & 13 & 89.8 \\
\hline 8 & 17 & 92.7 \\
\hline 9 & 16 & 95.5 \\
\hline 10 & 6 & 96.5 \\
\hline 11 and over & 20 & 100.0 \\
\hline
\end{tabular}

$10 \%$ of the longest time intervals between successive captures might occur when the animal left the study area for a certain period and then returned to it. The course taken by the distribution of time intervals between successive captures justifies acceptance of this method (Table 4).

It can be seen from Table 4 that $10 \%$ of the longest time intervals between captures occur during the period from seven months upwards. It was therefore considered that wild boar which are caught more often than every 6 months were constant residents in the study area, whereas when the interval between successive captures was 7 or more months the animals might have temporarily left the area.

Wild boar in their first year of life were omitted from the above analysis, since it was held that they have the same period of residence 
in the study area as their mothers (they do not migrate separately), while their being caught more often than older animals in corrals might erroneously alter the picture of relations in the material analysed.

On the strength of the above the period of stay of each individual in the study area was defined by means of the calendar of captures. The period during which animals over 6 months old were present in the study area before their first capture was taken (these were held to have a definite date of birth) as 6 months, and the period during which they remained after the last capture as the value of half of this time interval, (that is, 3 months) in accordance with the principles of material analysis using the calendar of captures method (Andrzejewski, 1969). The period of time before their first capture in the case of young wild boar was the time from their actual date of birth.

During observations of the animals from the turrets it was also found that unmarked individuals were present in the population which were never caught at all. These were solely individuals over one year old, most probably the majority of them being migrating animals. The number of observations of these animals was $22.7 \%$ in comparison with the number of observations of marked animals and this correction was accepted for estimate of population numbers obtained by means of the calendar of captures.

On account of the slight differences in this correction in the different study years $(1967-22 \%, 1968-22.4 \%, 1969-23.4 \%)$ the joint average value for 1967-1969 was also taken for 1966 and 1970, in which years no observations were made. The number of marked animals obtained from the calendar of captures plus the number of captures obtained from the above correction represents the dynamics of population numbers, and divided into age and sex classes, the age and sex structure of the population (Table 5).

The sex structure of the population throughout the whole study period revealed predominance of females, this increasing in the older age classes. The process of increased reduction of males during the first three years of life in the study population has been described by $\mathrm{J}$ e $\mathrm{z}$ i e r ski (1977).

\subsection{Reproduction and Population Age Structure}

Intensity of reproduction in different study years differed considerably (Table 6). During the period of intensive growth of the population the average number of young wild boar born, calculated in relation to all sexually mature sows, was very high. In 1967 it reached the average value defined by Oloff (1951) and Lebedev (1956) for gestating 
sows. This very intensive reproduction in 1967 most probably occurred as the result of supplementary feeding and abundance of acorns (an oak seed year) in 1966. During the subsequent three years the average number of young wild boar born constantly decreased, although it was still high in 1968.

\section{Table 5}

Sex and age structure of the population.

The estimate of the first age class does not include individuals which died during the first $6-8$ weeks of life (mortality among sucklings) since it was not until the 6-8 week that the animals began to appear in the corrals or were recorded during observations.

\begin{tabular}{|c|c|c|c|c|c|c|c|c|}
\hline & \multicolumn{2}{|c|}{$\begin{array}{l}\text { Up to on } \mathrm{e}^{-} \\
\text {yr old }\end{array}$} & \multicolumn{2}{|c|}{ Yearlings } & \multicolumn{2}{|c|}{$\begin{array}{l}\text { Over one } \\
\text { year old }\end{array}$} & \multicolumn{2}{|c|}{ Total } \\
\hline & & $\% *$ & $\mathbf{N}$ & $\% *$ & & $\% *$ & $\mathrm{~N}$ & $\%$ \\
\hline \multicolumn{9}{|l|}{1966} \\
\hline Males & 17 & 47 & 4 & 44 & - & 0 & 21 & 39 \\
\hline Females & 19 & 53 & 5 & 56 & 9 & 100 & 33 & 61 \\
\hline $\begin{array}{l}\text { Subtotal } \\
1967\end{array}$ & 36 & 66 & 9 & 17 & 9 & 17 & & \\
\hline Males & 25 & 48 & 9 & 30 & 7 & 41 & 41 & 41 \\
\hline Females & 27 & 52 & 21 & 70 & 10 & 59 & 58 & 59 \\
\hline $\begin{array}{l}\text { Subtotal } \\
1968\end{array}$ & 52 & 53 & 30 & 30 & 17 & 17 & & \\
\hline Males & 69 & 51 & 18 & 55 & 7 & 18 & 94 & 45 \\
\hline Females & 66 & 49 & 15 & 45 & 32 & 82 & 113 & 55 \\
\hline $\begin{array}{l}\text { Subtotal } \\
1969\end{array}$ & 135 & 65 & 33 & 16 & 39 & 19 & & \\
\hline Males & 31 & 47 & 25 & 46 & 15 & 35 & 71 & 44 \\
\hline Females & 35 & 53 & 29 & 54 & 28 & 65 & 92 & 56 \\
\hline $\begin{array}{l}\text { Subtotal } \\
1970\end{array}$ & 66 & 40 & 54 & 33 & 43 & 27 & & \\
\hline Males & 16 & 47 & 9 & 50 & 7 & 27 & 32 & 41 \\
\hline Females & 18 & 53 & 9 & 50 & 19 & 73 & 46 & 59 \\
\hline Subtotal & 34 & 44 & 18 & 23 & 26 & 33 & & \\
\hline
\end{tabular}

* The percentage of males and females in each class has been given, also the percentage of individuals in the given class, in the population (in italics).

Table 6

Varying number of young per one sexually mature female in successive study years.

\begin{tabular}{lccccc}
\hline Year & 1966 & 1967 & 1968 & 1969 & 1970 \\
\hline Young/female & 4.7 & 5.7 & 4.5 & 2.1 & 1.4 \\
\hline
\end{tabular}

The figure of approximately $15 \%$ mortality among sucking pigs was not taken into consideration in the above data ( $\mathrm{J}$ e zierski, 1977). Taking this estimate as a basis it is possible to calculate the correction for data in Table 6. It would then be necessary to increase the average 
number of young per one sexually mature female in 1966-1968 by about 0.8 , by about 0.4 in 1969 and about 0.2 in 1970 .

One of the factors conditioning the average number of young produced by a sexually mature female may be the age structure of the females living in the population. It proved possible to define the number of young reared by a certain number of females of an exactly known age. The material presented (Table 7 ) shows that the number of young produced increases up to the seventh year of life (cf. also M a u g e t 1972). Unfortunately the short study period, that is, short in comparison with the longevity of this species, did not permit evaluation of the form which reproduction takes at a later age. $\mathrm{H}$ a b e $\mathrm{r}$ (1969) considers, however, that older females reduce the number of young born, particularly in years with unfavourable climate or food.

Table 7

Average number of young reared depending on the age of the female.

\begin{tabular}{lccccc}
\hline Age of female & 1 year & $2-3$ years & $4-5$ years & $6-7$ years \\
\hline $\begin{array}{l}\text { Avg. number of young } \\
\text { Number of females }\end{array}$ & 1.0 & 3.4 & 4.0 & 5.0 \\
& 1 & 17 & 16 & 3 \\
\hline
\end{tabular}

Table 8

Number of wild boar shot.

\begin{tabular}{lccccc}
\hline Study year & 1966 & 1967 & 1968 & 1969 & 1970 \\
\hline Under one year old & 0 & 7 & 76 & 22 & 0 \\
Yearlings & 0 & 0 & 4 & 4 & 0 \\
Over one year old & 0 & 1 & 0 & 1 & 0 \\
\hline
\end{tabular}

In accordance with the principles accepted (A $n \mathrm{drz}$ eje w ski \& J e$z$ i e r ski, 1969) reduction of wild boar in the youngest age classes was carried out in 1967 in order to increase the percentage of older classes in the population (Table 8 ).

As a result increase was achieved in the reproductive part of the population from $17 \%$ in 1966 to $35 \%$ in 1979 (Fig. 2).

\subsection{Migration of Animals}

The process of exchange of individuals in a population was of an intensive but variable character depending on the life phase of the population (Table 9). During a period of increase in population numbers (up to 1968) the entry of individuals (immigration and reproduction) was 
approximately similar to the average population numbers in the given year, whereas disappearance of animals (emigration and mortality) fluctuated at about half of the average population number. In years when population numbers had a tendency to decrease the situation was the reverse: entry of individuals dropped to about half the average population numbers and disappearance increased to a value equal to average

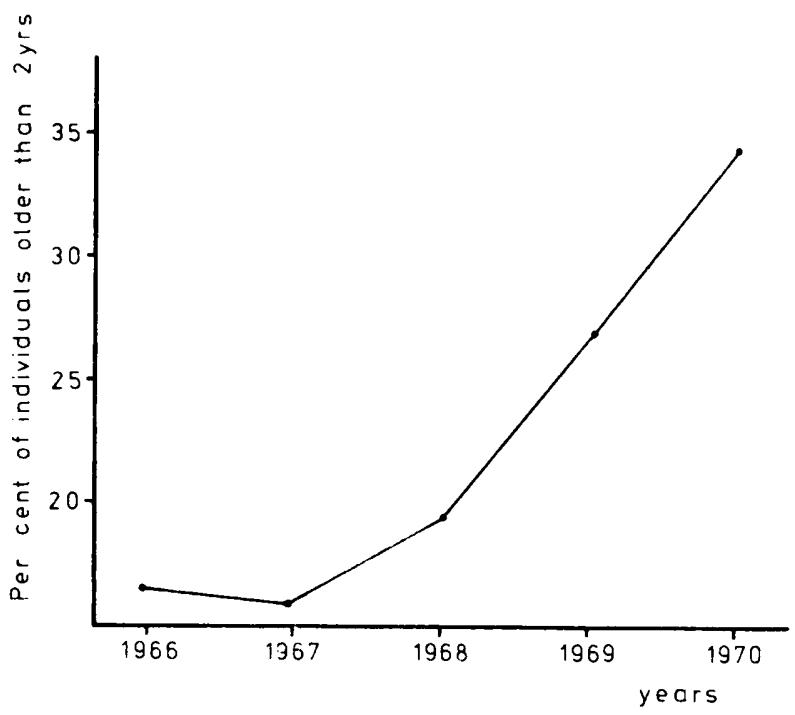

Fig. 2. Percentage formed by wild boar over 2 years old of total population numbers.

Table 9

Entry and disappearance of individuals in relation to average population numbers.

\begin{tabular}{lrrrrr}
\hline Study year & 1966 & 1967 & 1968 & 1969 & 1970 \\
\hline Entry in \% & 113 & 103 & 94 & 51 & 56 \\
Disappearance in $\%$ & 65 & 37 & 40 & 72 & 94 \\
\hline
\end{tabular}

numbers. The processes of entry of individuals took place chiefly at the expense of reproduction - during the whole study period settlement of only 58 immigrants was recorded (Table 10).

In all years (apart from 1967, in which disappearance of young wild boar was in general very slight) the greatest number of these young animals disappeared during the fourth quarter of the year. As $J$ e $z$ i e r$\mathrm{s} \mathrm{ki}$ (1977) has shown, this is due to increased mortality, since disappear- 
ance of adult wild boar (or possible emigration of the sows with their young) did not exhibit any distinct increase in these quarters.

In both years with large populations (1967 and 1968) disappearance of one-year-old wild boar, distributed over the whole year, greatly increased.

After period of peak population disappearance of the oldest age classes steadily increased. The largest number of animals disappeared in 1969, this applying to all categories of individuals. Emigration and immigration (excluding reproduction and mortality) of resident animals over one-year old and adult individuals took place in two main periods. The yearlings immigrate during the $14-15$ th months of life, that is, directly after the males reach sexual maturity, the family herds break up and new communities form, while adult wild boar immigrate during the period preceding mating (chiefly males).

An attempt was made on the basis of the material accumulated to estimate the extent of immigration by wild boar in the study area. Estimating the number of individuals who enter the study area and then settle there presented no great difficulty. These were all individuals revealed during the course of the studies as adults, that is, not born in the study area (which were usually marked during the first $3-5$ months of life) (Table 10) ${ }^{3}$.

There was intensive immigration of wild boar in 1967, that is, the year preceding the culminating dynamics of numbers of the study population. The frequency of entries and settlement of the animals then began to decrease and in 1970 reached a level similar to that in the initial year of the study.

On addition to individuals entering and settling in the study area, a group of individuals was observed may times in the population which remained in the area for such a short time that they were not caught.

Consideration must be given to residents in the study area, which on account of their individual peculiarities were not caught at all, (truly trap-shy) were not been included in this group of wild boar. Among 126 different marked and observed individuals there was not a single one which was not caught at least once during the six months period preceding observations of the given individual or during the 3 -month period following the given observation.

The question as to whether there is a decline in the trappability of wild boar with increasing age was also considered. The settlement of

3 Wild boar which revealed their presence during the first half of 1966 were considered to be animals present in the study area at the time the studies began, in accordance with the principles described in section 4.1 . 
Table 10

Number of wild boar entering and disappearing taken jointly and in different age classes.

\begin{tabular}{|c|c|c|c|c|c|c|c|c|c|c|c|c|c|c|c|c|c|c|c|c|c|c|c|c|c|}
\hline Study year & & 19 & 66 & & & & & 1967 & & & & & 196 & & & & & 69 & & & & 1970 & & & \\
\hline Quarter & I & II & III & IV & $\Sigma$ & I & II & III & IV & $\Sigma$ & $I$ & II & III & IV & $\Sigma$ & I & II & III & IV & $\Sigma$ & $\mathbf{I}$ & II & III & IV & $\Sigma$ \\
\hline Entering: & - & 40 & 10 & 11 & 61 & 7 & 57 & 25 & 13 & 102 & - & 62 & 25 & 7 & $1 \overline{94}$ & 9 & 61 & 11 & 2 & 83 & 4 & 34 & 6 & - & $\overline{44}$ \\
\hline one year old & - & 40 & 9 & 8 & 57 & 4 & 49 & 18 & 5 & 76 & - & 60 & 14 & 4 & 178 & 6 & 60 & 9 & - & 75 & 3 & 32 & 5 & - & 40 \\
\hline yearling & - & 一 & - & 3 & 3 & 2 & 6 & 1 & 4 & 13 & - & 1 & 4 & 1 & 6 & 1 & - & 1 & - & 3 & 1 & - & - & - & 1 \\
\hline adults & - & - & 1 & - & 1 & 1 & 2 & 6 & 4 & 13 & - & 1 & 7 & 2 & 10 & 2 & 1 & 1 & 1 & 5 & - & 2 & 1 & 一 & 3 \\
\hline Disappearing: & - & - & 10 & 26 & 37 & 1 & 9 & 15 & 7 & 32 & 15 & 23 & 9 & 26 & 73 & 13 & 28 & 28 & 33 & 102 & 10 & 24 & 4 & 22 & 60 \\
\hline one year old & - & 一 & 2 & 20 & 22 & 1 & 一 & 3 & 3 & 7 & 12 & - & 3 & 8 & 33 & 7 & - & 2 & 14 & 23 & 3 & - & 1 & 11 & 15 \\
\hline yearlings & - & 1 & 5 & 3 & 9 & - & 8 & 7 & 3 & 18 & 3 & 19 & 4 & 2 & 28 & 4 & 15 & 20 & 11 & 50 & 3 & 10 & 2 & 4 & 19 \\
\hline old animals & - & - & 3 & 3 & 6 & - & 1 & 5 & 1 & 7 & - & 4 & 2 & 6 & 12 & 2 & 13 & 6 & 8 & 29 & 4 & 14 & 1 & 7 & 26 \\
\hline
\end{tabular}


old wild boar in the study area might then not be recorded during captures and these animals might have been considered ephemerals. Among the wild boar born in 1966 and 1967 in the study area all those $(N=18)$ which remained in this area up to the end of the study period were selected and a chart of distribution of captures in successive years of their life drawn up for them (Table 11). It proved that it was only the first year of life of these animals which is characterized by a higher degree of trappability $(P<0.05)$, whereas in subsequent years of life no statistically significant differences are found in their trappability, which remains on an approximately uniform level $(P>0.05)$.

The above analyses permitted the assumption that in principle all unmarked wild boar over one year old and observed in the study area are ephemeral individuals.

The impossibility of individual differentiation between the animals made it out of the question directly to define the number of ephemeral wild boar living in the study area at different periods of time. This figure

Table 11

Percentage of number of captures of wild boar in successive years of life of young animals which survived in the study area for at least 4 years $(\mathrm{N}=291)$.

\begin{tabular}{lcccc}
\hline Year of life & First & Second & Third & Fourth \\
\hline Percentage of captures & 42 & 23 & 16 & 20 \\
\hline
\end{tabular}

may be indirectly assessed as follows: in accordance with the foregoing discussion the maximum time that an ephemeral wild boar remains in the study area must have been shorter than 6 months, and therefore the average period of their stay must have been shorter than 3 months. This means that on en average the number of ephemeral wild boar changed more than 4 times a year. Since the ratio of marked to ephemeral (unmarked) animals was $22.7 \%$ of animals over one year old, it may be concluded that the number of ephemeral wild boar which passed through the study area every year must have been similar to the total average number of resident yearlings and adults in each year.

It did not prove possible to estimate the intensity of the emigration of wild boar from the study area, since the group of disappearing animals included both emigrating individuals and mortality. The material accumulated, on account of the shortness of the study period in relation to the age of the wild boar, did not permit the estimation of the distribution of these two groups. In addition very little information was obtained on marked wild boar shot outside the study area. Andrzejewski 
(1971) mentioned two such animals, and apart from this information was received about three further emigrants. Of these five return reports on wild boar, one was shot at a distance of $5 \mathrm{~km}$ from the place of its marking on the right bank of the Vistula (and must thus have swim across the river which is about $700 \mathrm{~m}$ wide), one at a distance of about $90 \mathrm{~km}$, two about $170 \mathrm{~km}$ (one to the north, the other to the west) and one at a distance of over $250 \mathrm{~km}$. This data shows how far afield the wild boar migrates.

On account of the over-short study period it was not possible either to estimate the true mortality among wild boar. Jezierski (1977) showed for the same population, which was examined over a period of 12 years, that this mortality is very great, as much as $84 \%$ during the first two years of life, with maximum observed longevity of 9 years and average length of life 25 months.

On the basis of the dead boar found (penetration of the study area was approximately the same throughout the whole period) it may be concluded that mortality was highest in 1969 (Table 12). An important

Table 12

Number of wild boar found dead in different years and quarters (I-IV).

\begin{tabular}{lrrrrr}
\hline Year & I & II & III & IV & Total \\
\hline 1966 & & & & & \\
1967 & 2 & - & - & - & - \\
1968 & 5 & 1 & -2 & 2 & 5 \\
1969 & 5 & 1 & 9 & 1 & 10 \\
1970 & 11 & 1 & - & 1 & 16 \\
Total & 23 & 3 & 11 & 7 & 42 \\
\hline
\end{tabular}

cause here was undoubtedly the weather conditions, exceptionally difficult for the study area, which occurred in 1969/70 (very deep snow cover). This is indicated by the fact that during the first quarter of 1970 no less than 11 dead wild boar were found which, in the light of $\mathrm{J}$ ez i e r s ki's study (1977), must be considered as a phenomenon differing from the rule. It would however appear that the chief cause of such high mortality lay in intrapopulation phenomena, since the greatest mortality among yearlings and adult animals began even before the severe winter set in (Table 10) and during the subsequent years the population passed into a phase of declining population ( $\mathrm{J}$ e $\mathrm{z}$ i e r s ki \& M y r$c h a, 1975)$. This is in fact in agreement with current opinions on the role played by intrapopulation factors in respect to numbers control in a population with a structure-derivative type of dynamics of numbers 
(Na umov \& Nikolskij, 1962; Petrusewicz, 1965; Jezierski, 1976).

\subsection{Variations in Numbers}

Variations in numbers of the study population are the result of the processes of settlement, entry and disappearance and the control procedure carried out (Fig. 3). The rapid increase in numbers from 1966--

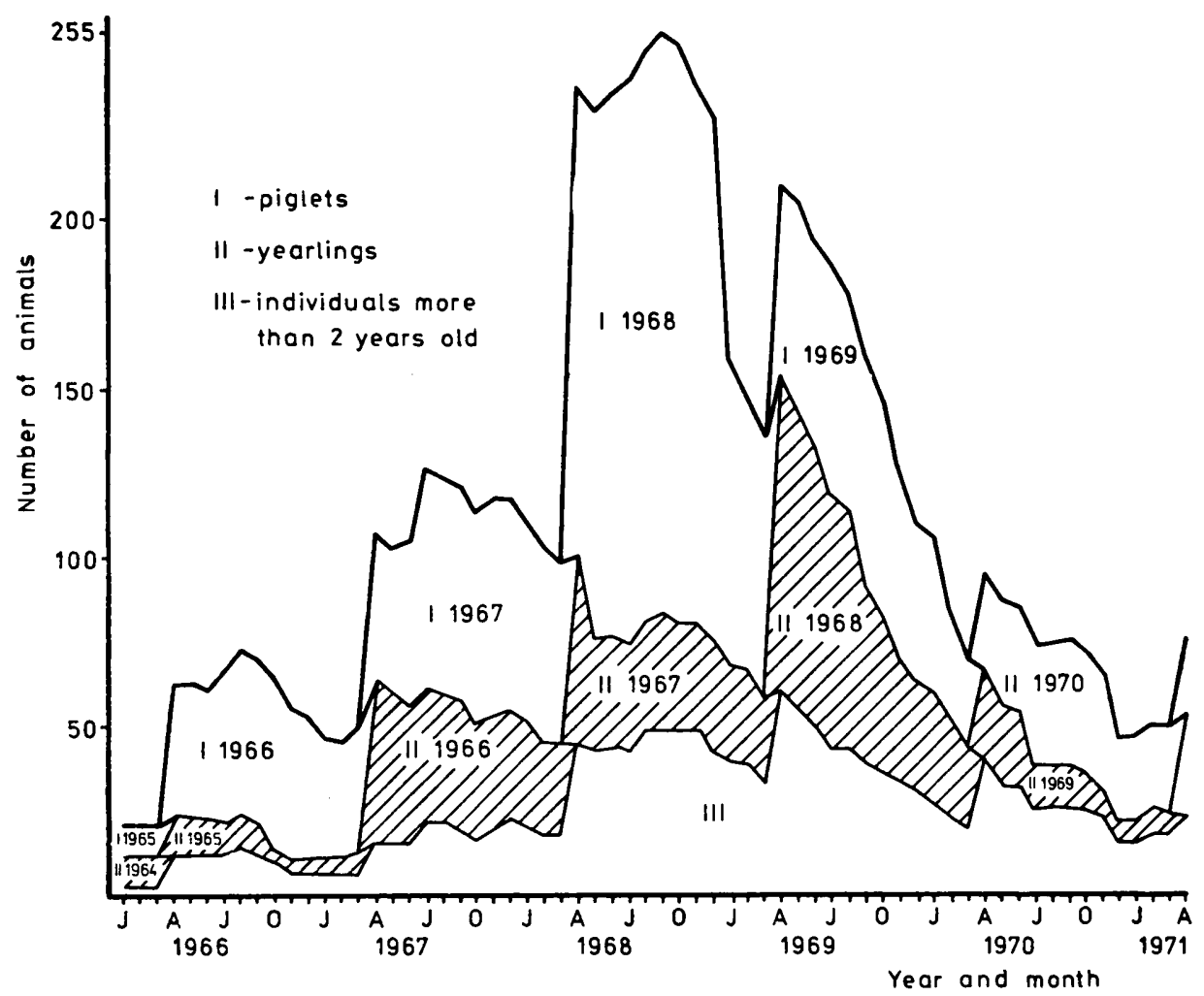

Fig. 3. Variations in numbers in a wild boar population from 1966-1970. Numbers assessed from calendar of captures and corrected by the percentage of unmarked wild boar in the population.

-1968 and abrupt decrease in numbers during 1969 are remarkable. It has previously been shown that this decrease took place primarily at the expense of yearlings and the oldest age classes. Mortality among young animals due to climatic conditions during the winter of $1969 / 70$, and the low actual increase connected with these conditions in 1970, were the causes of the drop in numbers in 1970. According to data 
obtained from the administration records of the Kampinos National Park, the numbers of wild boar in the study area in years preceding these studies were far smaller (Table 2) than in 1970. From 1971-1972 numbers were slightly lower than in 1970 and remained on a level of 50-60 animals (J e zi ers ki \& M y r cha, 1975).

\section{FEEDING ACTIVITIES OF THE POPULATION AND EXTENT OF DAMAGE DONE ON AGRICULTURAL LAND}

\subsection{Daily Feeding Activity Rhythm and Annual Feeding Cycle}

An estimate was made of what percentage of the period the feeding site was supplied with food at each hour of the day $(60 \mathrm{~min}-100 \%)$ was used by the wild boar for uninterrupted feeding. The following intervals were accepted: up to $5 \%$ - occasional feeding, $5.1-20 \%$ limited feeding, $20.1-50 \%$, moderately intensive feeding and $50.1-$ $75 \%$ - intensive feeding - of the time the feeding site was in operation. None of the feeding sites was used for more than $75 \%$ of the time it was in operation. Calculation was made for 2-hour time intervals of the average values of time during which use was made of a feeding site by wild boar and the results set out in diagram form for the period 1966-1969 (Fig. 4).

At the end of 1966 and beginning of 1967 there was an interval in consumption of food supplied on the feeding sites, due to the abundant autumn fall of acorns.

The daily rhythm of feeding activity was primarily determined by periods of day and night (sunrise and sunset), but the density and social organization of the population also exerted a certain influence on this phenomenon.

Intensive and moderately intensive feeding was limited chiefly to the time between sunset and sunrise. As population numbers rose from low to average (1966 and 1967 - Fig. 3) the time for which the feeding sites were in operation became greatly occupied by intensive feeding. At the same time the total time for which use was made of the feeding troughs lengthened. During the year of maximum population numbers (1968) the total time of feeding from troughs continued to increase, while simultaneously intensive use of the throughs decreased in favour of moderately intensive feeding. This means that there was a further increase in the feeding activity of the population. An excessive number of wild boar must also have begun to occur in relation to the number of supplementary feeding sites and reciprocal jostling of groups of animals at the troughs must have increased. As shown by observations from the tur- 
rets, a considerable part of the time when the troughs were not used, particularly during the period of intensive and moderately intensive feeding, is spent for exchange of groups of wild boar at the troughs. The

1966

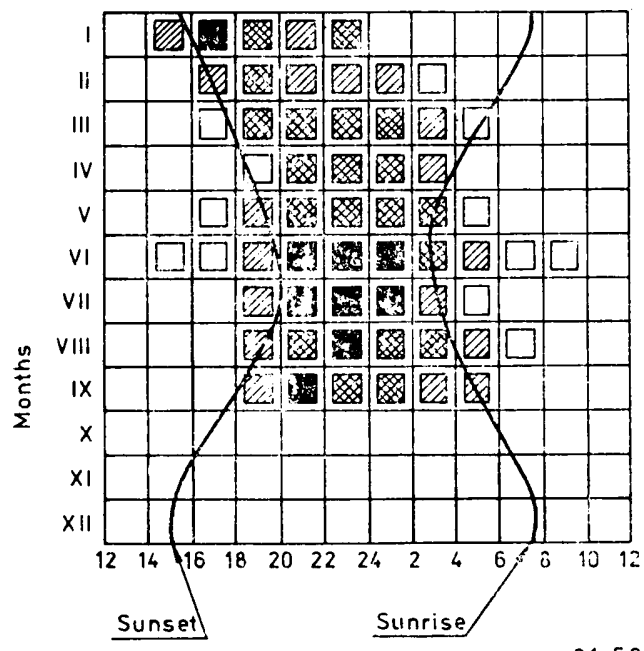

1907

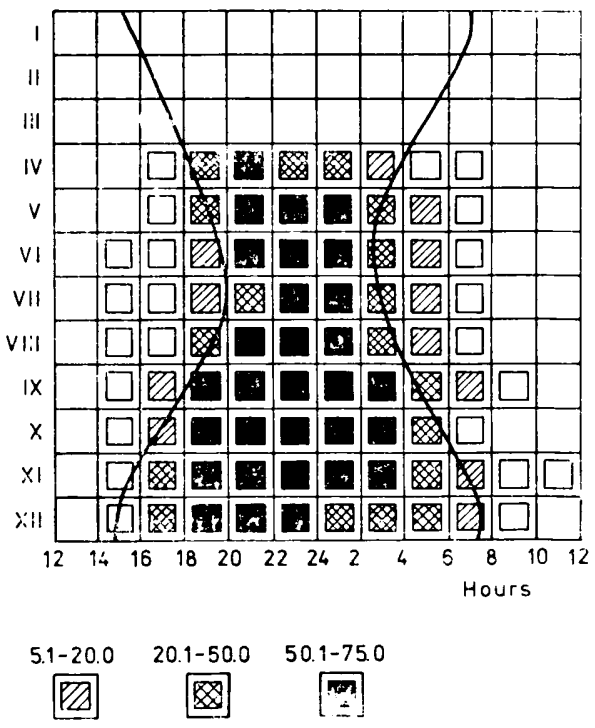

1969

1968
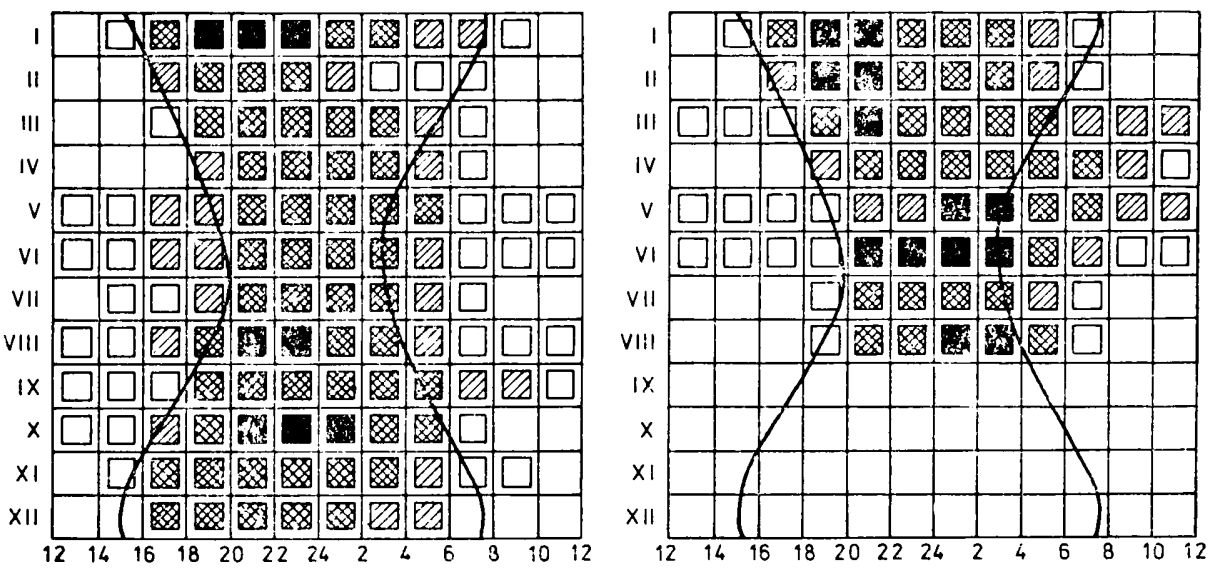

Fig. 4. Degree to which feeding troughs are used by wild boar over the yearly cycle in percentages of the time of availability (on a four-degree scale). Curve illustrates sunsets and sunrises.

cause of such exchange was the lack of reciprocal tolerance between groups and the territorial relations in the groups. 
In 1969 , which was distinguished by a certain decrease in population numbers (Fig. 3), but at the same time by an increase in the number of groups, the total time during which use was made of the feeding troughs was similar to that in 1968, while moderately intensive and limited feeding also shifted to the daytime period up to mid-day (Fig. 4). This means that with total activity similar to that in the preceding year, the animals, split up into a greater number of groups, could not fit into the space round the troughs during the night time and satisfied their hunger during the daytime period also, which they were never observed to do in earlier years.

The picture obtained above is confirmed by the average amounts of oats consumed by an average wild boar (Table 13). In 1967, (in 1966 no material of this kind was collected), characterized by great intensity of feeding, the average was very high. The subsequent two years with similar distribution of feeding time, although with slightly differently distributed intensity, showed the same average amount of oats consumed daily, but less than the average for 1967. The lowest average was found for 1970. This decrease was due to two factors. In the first quarter of

Table 13

Average amount of food (in $\mathrm{kg}$ ) consumed daily by one average wild boar.

\begin{tabular}{lllll}
\hline Year & 1967 & 1968 & 1969 & 1970 \\
\hline $\mathrm{kg} /$ individ./day & 0.96 & 0.68 & 0.70 & 0.51
\end{tabular}

this year feeding very distinctly decreased due to the deep snow cover making it impossible for the wild boar to move about freely. During the fourth quarter feeding also markedly declined, due to the abundant fall of acorns connected with an oak seed year (although not as abundant as in 1966).

An attempt was made at estimating what part of the wild boar's daily food requirements was satisfied by food obtained from feeding troughs. Jezierski \& Myrcha (1975) calculated that average daily energy requirements (less the energy required for storing fat) of a statistical wild boar varies between 2500 and $500 \mathrm{kcal} /$ individual $/ 24$ hours. They also showed that the energy in $1 \mathrm{~kg}$ of oats (after subtracting the diminishing coefficient for, wastefulness of feeding) was about $3250 \mathrm{kcal}$. It is easy to calculate from this that daily feeding by wild boar in the feeding troughs on an average supplied from one third to two thirds of their energy requirements.

It is obvious that the above calculation has all the defects of calculated 
average indexes. In different months of different years the true situation was capable of fluctuating from almost complete to $1 \%$ satisfaction of assimilation requirements of the population by food consumed from the feeding troughs. Jezierski \& Myrcha (1975) have shown that even when food is supplied ad libitum it is of a supplementary nature only.

Both the distribution of time during which use was made of the feeding troughs (Fig. 4), and dynamics of damage caused by wild boar over the annual cycle (Fig. 5), show that maximum feeding takes place, under

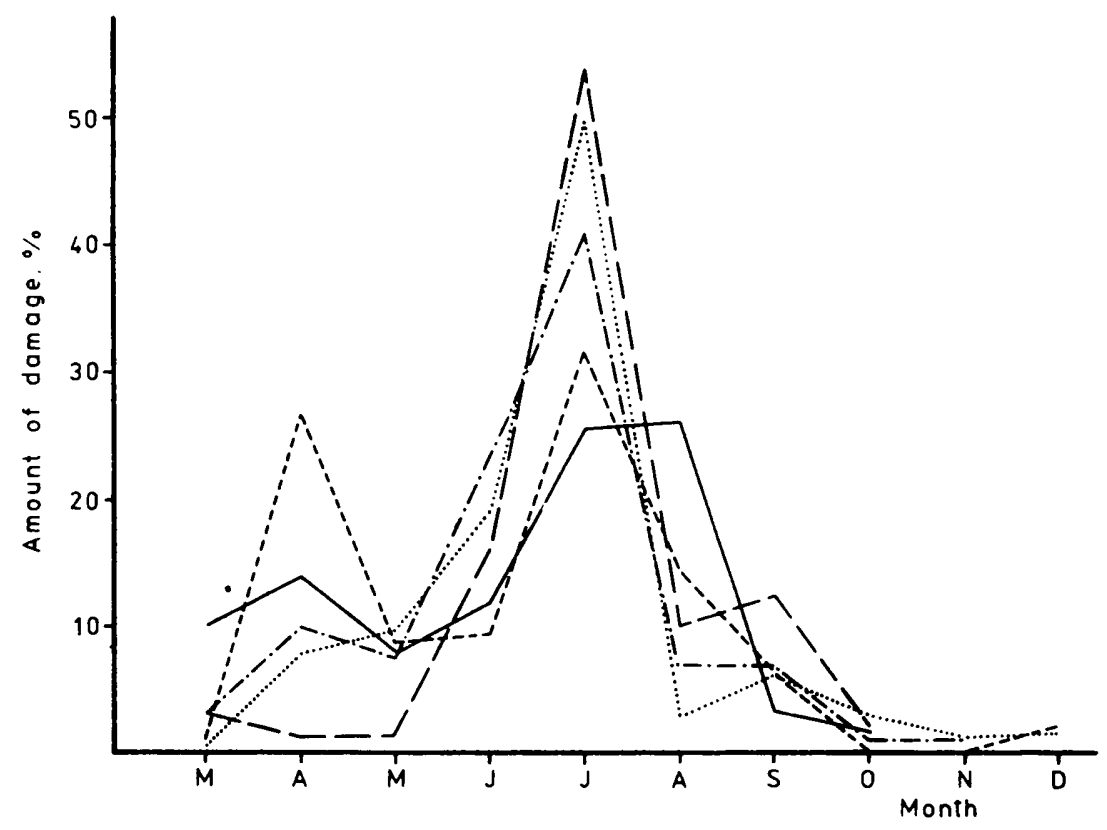

Fig. 5. Distribution of frequency of damage caused over the yearly cycle.

conditions prevailing in Poland, during the period from May to September. Attention has been drawn earlier to this phenomenon by A $\mathrm{nd} \mathrm{r} \mathrm{z} \mathrm{e-}$ jewski \& Jezierski (1969) and M a ckin (1970), who emphasized inter alia its dependence on the phenological cycle of plants. It would however appear that the main factor controlling this phenomenon is food requirements and not availability of food. This is indicated by the variable average daily amount of oats consumed at different seasons of the year, despite the fact that the food was available ad libitum (Table 14). During the period from January to April when the amount of netural food is smallest, the amount of supplementary food consumed wes 
also the smallest. From May to September, when in general maximum abundance of plant food occurs, the amount of supplementary food consumed also increased very markedly. Finally, during the last quarter of the year (apart from oak seed years), consumption of supplementary food either increased or was maintained on the same level. It is possible that this is connected with the pre-winter period of accumulating fat on the bodies of wild boar.

A ndrzejewski et al. (in prep.) made an analysis of the frequency of the average number of individuals seen during one observation, average for one observation post, separately for each month in 1968. They found that the minimum number of individuals approaching the feeding sites occurred in April and May (11 individuals per day) and maximum in July and August (57 individuals per day). The second peak of this kind occurred in October ( 38 individuals per day). In the other months

Table 14

Total and average daily amount of oats consumed.

\begin{tabular}{ccccc}
\hline \multicolumn{5}{c}{$\begin{array}{c}\text { Average daily amount of food } \\
\text { consumed per feeding site in } \mathrm{kg},\end{array}$} \\
Year & I-IV & $\begin{array}{c}\text { months: } \\
\text { V-XI }\end{array}$ & X-XII & Total \\
\hline \multirow{2}{*}{1967} & 11.3 & 16.8 & 22.2 & 23.6 \\
1968 & 14.6 & 23.5 & 31.5 & 51.0 \\
1969 & 25.3 & 26.1 & 24.9 & 41.7 \\
1970 & 11.4 & 19.8 & 8.0 & 14.6 \\
\hline
\end{tabular}

visits to feeding troughs were maintained on a fairly even level of 20 to 30 individuals per day. This picture closely corresponds with that described previously.

\subsection{Amount of Damage Caused by the Study Population in Agricultural Land}

The amount of damage caused by the study population of wild boar in neighbouring fields exhibits considerable variability in different years (Fig. 6). This variability, on account of the specific situation connected with supplementary feeding, does not reveal any correlation with changes in population numbers (Table 2). It must however be emphasized that the amount of damage done on commercial land exhibits only a slight relation to population numbers, even when no effect of any kind is exerted on the wild boar population ( $\mathrm{M} \mathrm{a} \mathrm{ck} \mathrm{in,1970).}$

In the case in question, as the result of intentional action (supplementary feeding and change in age structure), despite the threefold increase in population numbers the amount of damage decreased by half (from 
1963 to 1967) and with sevenfold increase in population numbers (from 1965 to 1968) by one-third. In connection with the population's food requirements varying in time and with variable intensification of their feeding, an estimate was made of which months were of decisive importance to the total amount of damage done (Table 15).

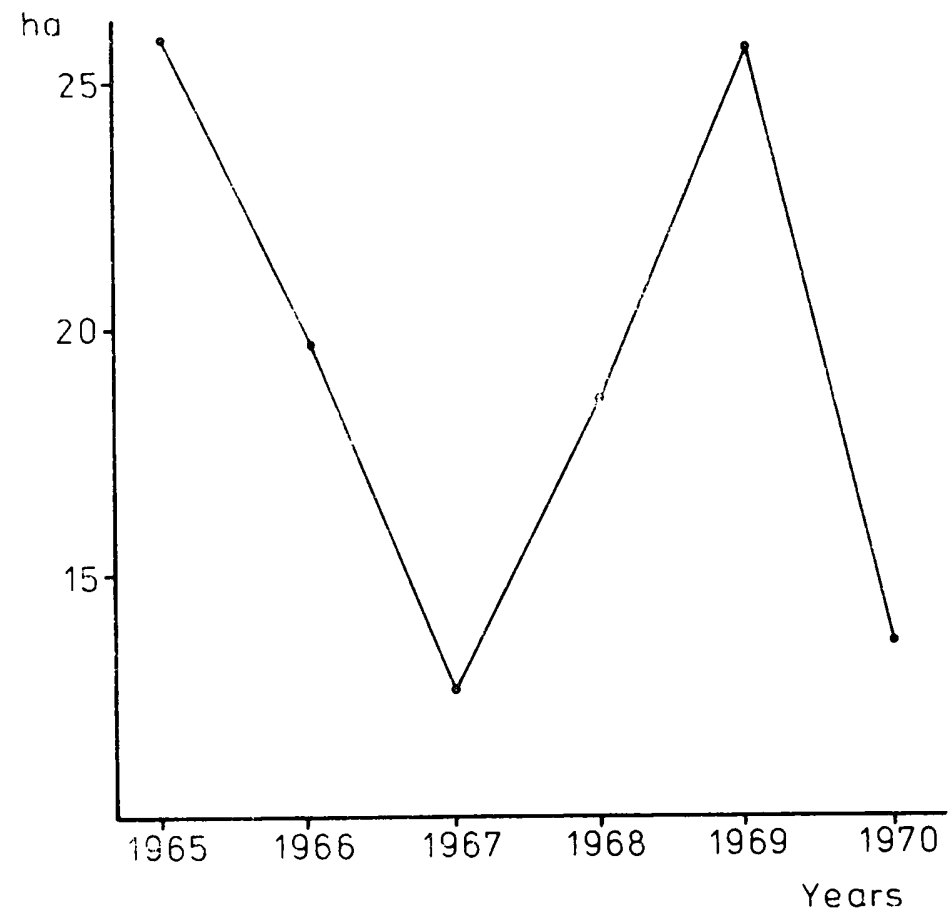

Fig. 6. Amount of damage caused by the study population of wild boar in cultivated crops.

Table 15

Amount of damage caused during summer period in percentages of total annual amount of damage.

\begin{tabular}{lccccccc}
\hline $\begin{array}{l}\text { Damages } \\
\text { caused in } \\
\text { months }\end{array}$ & 1965 & 1966 & 1967 & 1968 & 1969 & 1970 & Average \\
\hline V-VIII & 77.9 & 70.5 & 80.9 & 77.9 & 80.2 & 65.7 & 75.8 \\
V-IX & 83.2 & 73.6 & 93.1 & 85.4 & 86.4 & 71.8 & 82.1 \\
\hline
\end{tabular}

Attention has been given to this problem by Mackin (1970), who showed that this phenomenon depends on plant phenology. It may be accepted for the conditions found in the study area that the amount of damage done is determined by the period from May to August. April 
also, in all the study years apart from 1967, was characterized by a relatively large amount of destruction of crops. That was a month in which feeding in the wooded parts ceased completely ( $\mathrm{J}$ e zi e r ski \& M y r$\mathrm{ch} \mathrm{a}, 1975)$ and feeding in the feeding troughs decreased considerably. Intensification of feeding in fields during this period was probably connected with the specific food requirements of the population, which could not be satisfied by food from the forests or in the feeding troughs. Further research should be done for the facts connecting this phenomenon with the start of the period of births of young during this month.

Table 16

Percentage of rye, oats and potatoes in total area of cultivated land in fields of the study area (average for 1965-1970), after data of local administration offices, and percentage of these crops in total area of destroyed crops (average for 1965-1970).

\begin{tabular}{lcccc}
\hline Kind of crop & Rye & Oats & Potatoes & Jointly \\
\hline $\begin{array}{l}\text { Percentage in total area in \% } \\
\begin{array}{l}\text { Percentage of crops destroyed by wild } \\
\text { boar in \% }\end{array}\end{array}$ & 33.8 & 6.9 & 28.9 & 69.6 \\
\hline
\end{tabular}

In the study area $97.8 \%$ of the damage was caused on rye, oats and potato crops. There were very little differences in this amount in different study years and for the combined destroyed area of these three crops came within the limits of $95.5 \%$ to $100 \%$. The areas of these crops were compared with their percentage in the total area of cultivated plants (Table 16), and it was found that destruction of these crops by wild boar was markedly greater than their percentage in the total area of cultivated fields. Particular preference was shown for oats, intensity of feeding on which was twice greater than would have resulted from random feeding, and for this reason, oats which were supplied in the feeding troughs.

\section{DISCUSSION}

A specific course of dynamics of numbers was obtained in the study population of wild boar. The period of stabilized populations was followed by rapid increase to about $770 \%$ of the initial numbers, after which there was an equally rapid decrease and in turn stabilization of population numbers on a level twice higher than the numbers of the population before the period of increase.

While increase in numbers takes place almost solely by means of reproduction, decrease in numbers occurred only partly as the result of 
reduction in actual increase, but to a predominant extent as the results of disappearance from the population of wild boar aged two years or over. Let us discuss the causes of this course taken by variations in numbers.

Populations of different species of animals are characterized variable life phases during the course of their existence and disturbances in population structure or organization may cause induced increase in numbers ( $\mathrm{Petr}$ u e w i c $\mathrm{z}, 1958,1963,1965)$. It is also considered that in the case of the wild boar (and many other species) abudance of food induces increased reproduction, and consequently increased population numbers (O l off, 1951; Le bedeva, 1965; H e p tne r et al., 1961;

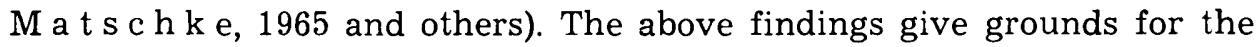
opinion that the increase in numbers of a wild boar population described above took place as a result of their supplementary feeding ad lib. throughout the whole year with high-caloric food. This factor operates however only up to the time when the population reaches a density of about 1000 individuals per 1000 ha.

Next, although availability of food continued to be the same (in the year of decrease in numbers the average amount of food consumed per day by an average wild boar was the same as in the year of maximum population increase and its maximum numbers), population numbers dropped and became stabilized on a new level. The cause of these changes is thus independent on the food factor.

It would appear possible to agree with Petrusewicz (1965) in holding that the causes of such changes in population dynamics lie in intrapopulation factors. It seems that the following were primarily responsible for the changes observed in numbers of wild boar: change in the population's age structure by increasing the percentage in the population of older age classes (Fig. 2) and the consequent increase in contacts between individuals and groups caused by the greater activity of the animals, and also the increase in the number of groups in the population (A ndrzejewski et al., in prep.). Thus the "aging " of the population with simultaneously high density caused a slight decrease in the actual reproduction (Table 6) and a high degree of disappearance of animals over one year old (emigration and mortality). Such disappearance began as early as the summer period (favourable in respect of conditions for survival) and a high mortality rate during the severe winter of $1969 / 70$ also contributed to this process. This mortality might in fact have been partially due to this process acting on animals subjected to intensification of social stress.

A significant phenomenon in control of population numbers of wild 
boar is their considerable tendency to migrate and the wide range of migration of different individuals. Of the individuals entering a given population in each year, individuals disappearing from the population in a given year (and which were resident in it) and ephemeral individuals are counted jointly, then the "traffic " of individuals in a population was from 150 to $200 \%$ of the average annual numbers of a settled population. The course and intensification of in- and out-flow of migrating individuals and the existence in the population of a group of ephemeral individuals indicate that migration processes in the case of the wild boar have a similar specific character, intensification and course to those described by a large number of authors in respect of small mammals ( $\mathrm{R}$ a $1 \mathrm{l}$, 1936; Petrusewi c z \& Andrzejewski, 1962; Andrzejewski, 1963; Krebs, Keller \& Tamarin, 1969 and many others).

It may therefore be anticipated by analogy, that in the case of wild boar the controlling role of migrating in relation to the dynamics of their numbers is similar to that in small mammals. Migrational tendencies may, however, have specific results connected with hunting management for a wild boar population treated geographically. For instance migrating individuals may constantly maintain numbers in areas in which these animals are kept down on account of the great damage they do in agriculture. Energetic elimination of wild boar in such areas results in the areas becoming a special kind of "trap " attracting migrating individuals from large areas.

The local population is greatly affected by the group of individuals entering upon a migrating state (emigrating) and settling (immigrating to settle) and the group of ephemeral individuals (only passing through the population). It has been shown that the entry and disappearance of settled individuals in periods when they do not balance each are of fundamental importance to the dynamics of population numbers. The presence in the population of ephemeral individuals, although to some extent forming the current population numbers, do not affect the dynamics of changes in this process. This is so because the percentage of ephemeral individuals exhibits only slight variation in relation to the numbers of settled individuals more than one year old. The amount of migrating individuals passing through the population is thus proportionally dependent on the size of the settled part of the population.

Andrzejewski (1963) has already drawn attention to the phenomenon described above, but in relation to small rodents. In the case of wild boar this relation was great and therefore did not modify the dynamics of population numbers. Variations in numbers were the result chiefly of migration of settled individuals, immigration being of only 
slight significance to it (apart from 1967). During the whole study period it was only $12 \%$ of the individuals which increased the numbers of the settled part of the population, whereas the remaining $88 \%$ of increase in numbers was due to reproduction.

The age structure of disappearing animals, however, took a different form. Among the animals less than one year old were found only $34 \%$ (not including mortality among sucking pigs) and as Jezierski has shown (1977) this is due solely to disappearance due to mortality. The remainder is formed by animals over one year old, as much as $61 \%$ being formed by yearlings. Despite the fact that so many animals disappear during the first two years of life, the very high reproduction and equally high mortality among individuals as from the sixth year of life upwards (Jezierski, 1977) and also the specific way in which they are used for game purposes, with preference for shooting large wild boar (old), cause excessive reduction in the average age of individuals in a population of wild boar and the inevitable consequences of this state of affairs in the population. The material presented in these studies thus supports the opin:on as to the necessity for control by game management of the age structure in wild boar populations (W a g e $\mathrm{n} \mathrm{k} \mathrm{n} \mathrm{e} \mathrm{ch} \mathrm{t,}$ 1962; Andrzejewski \& J ezierski, 1969; Jezierski, 1976).

The starting point for estimating the possibility of limiting the damage done by wild boar in cultivated crops is the relation between intensification of such damage and population numbers. It has been shown that population numbers constitute a factor which affects to a slight degree only the amount of damage caused by the population, which confirms the results obtained previously by $\mathrm{Mackin}$ (1970). The age structure of the population and the social structure connected with it, stimulating intensification of aggressive contacts between groups and within them, are of far greater importance. This leads to the population's splitting up into groups of smaller numbers (A ndrzejewski et al., in prep.). With a large number of small groups in the population not all of them are able to make use of attractive food when it occurs in a limited number of places. This may produce a dual result, depending on the trophic structure of the habitat in which the population lives. If the limited number of sites of attractive food are situated in fields, the splitting of the population into small groups and increased competition for food between them reduces the amount of damage done. If, however, attractive food competing with food in fields, is present in wooded land in limited amounts, the division of the population into small grcups causes an increase in the damage done in fields. The decrease in darage observed in 1968 and 1969 was due to this cause. 
It can be seen from the above discussion that the basic factor influencing the amount of damage caused by wild boar in fields is the occurrence or lack of attractive food in wooded land. Mass occurrence of such food, for instance, acorns in oak seed years (and certainly beech nuts and mass irruptions of insects etc.) was instrumential in almost entirely eliminating the feeding of wild boar on other foods. A similar effect could be achieved by introducing into a forest habitat food such as oats or maize. It has been shown that in such cases it is possible to obtain very considerable reduction in damage, despite the simultaneous increase in population numbers (Table 2 and 14 ; Fig. 6). In order to make this operation fully effective it is, however, essential a watch at the same time changes in social structure and to adapt the number of supplementary feeding places to the current state of this structure.

The damage done during the period from May to August is of great economic importance. Bearing in mind that the population must have enough time to adapt its feeding habits to the changed spatial food relations, it would be necessary to begin supplying supplementary food about the middle of April and continue this supply up to the end of August. The daily portion per wild boar in the population required to obtain maximum effect should be from 0.7 to $1.0 \mathrm{~kg}$ of oats (Table 14), which means that supplementary feeding of wild boar during this period should be in amounts less than $1 / 3-1 / 2$ of their daily food requirements.

This considerable amount of supplementary food for the population during the period when they cause maximum damage in fields would permit management of density on an average level of about $30-40$ individuals per $1000 \mathrm{ha}$ of forest, with a high degree of exploitation of $40 \%$ of the total, with a low level of damage. This is of course a postulate differing greatly from the opinions held by the majority of European authors concerned with the problem of what is known as "game area capacity" for the wild boar and whose recommendations have been given in the paper by $\mathrm{H}$ a ber (1969). In these recommendations, with the exception of one case, the proposed population density of wild boar fluctuates within limits of 1 to 10 individuals per 1000 ha of forest. In the light of the material presented in the present paper it may be concluded that there is in principle no need (or possibility) of maintaining the density of a wild boar population on a level below that of 10 individuals per 1000 ha of forest. Taking into consideration the well known ecological principle put forward by A 11 e e (1938) of optimum density of a population for its development, and Petrus e w i c z's opinions (1963) on the role which density plays in a population, it would not appear possible for a wild boar population with density below 10 individuals per 1000 ha 
of forest to exist continuously in time without constant immigration of individuals from areas in which density was greater ${ }^{4}$.

The studies presented here thus draw attention to three factors of importance to obtaining a high degree of productivity from a wild boar population with limitation of the amount of damage caused by this population in fields: the age and sex structure of this population, its considerable tendency to migration and distribution of attractive food within wooded land and adjacent fields.

Acknowledgements: The authors are greatly indebted to W. Filipiak M. Sc., head of the group of laboratory assistants taking part in these studies, for his tireless and devoted technical assistance, initiative and ingenuity in constructing devices for the studies, and for his contribution to these studies which went far beycnd the normal limits of his immediate duties. The authors also wish to thank Dr. K. M or ow for statistical analysis of material relating to the feeding activities of wild boar.

\section{REFERENCES}

1. Alle e W. C., 1938: The social life of animals. Norton: 1-233. New York.

2. Andrzejews'ki R., 1963: Processes of incoming, settlement and disappearance of individuals and variations in the numbers of small rodents. Acta theriol., 7, 11: 169-213.

3. Andrzejewski R., 1969. Analiza wyników połowów drobnych ssaków metodą „kalendarza złowień". Zesz. nauk. Inst. Ekol. PAN, 2: 1-104. Warszawa.

4. Andrzejewski R., 1970: Wędrówki dzików. Łowiec pol., 9 (1932): 7.

5. Andrzejewski R. \& Jezierski W., 1969: Zasady przeciwdziałania szkodom wyrządzanym przez dziki. Eowiec pol., 1 (1340): 4-6 and 2 (1341): 2-3.

6. B o b a ck A. W., 1957: Das Schwarzwild. J. Neumann Verlag: 1-92. Neudamm.

7. Briedermann L., 1968: Die biologische und forstlische Bedeutung des Wildschweines im Wirtschaftswald. Arch. Forstwes., 17, 9: 943-967.

8. Bujalska G., 1970: Reproduction stabilizing elements in an island population of Clethrionomys glareolus (Schreber, 1780). Acta theriol., 15, 25: 381-412.

9. Dombrowski R., 1896: Die Wildschaden. Voigt Verlag: 1-87. Weimar.

10. Eck J., 1929: Wald und Wildhege. Meyer Verlag: 1-242. München.

11. Ermich K., 1951: Wskaźniki klimatyczne dla gospodarstwa leśnego w Polsce. Państw. Wyd. Roln. i Leśne: 1-24. Warszawa.

12. Haber A., 1967: Znaczenie dzika w biologicznej ochronie lasu. Zesz. nauk. Szk. Główn. Gosp. Wiejs. Ser. Leśnictwo, 9:

13. H a ber A., 1969: Dzik. Monografia przyrodniczo-łowiecka. Państw. Wyd. Roln. i Leśne. 1-216. Warszawa.

14. Heptner V.G., Nasimovið A. A. \& Bannikov A. G., 1966: Die Säugetiere der Sowjetunion. 1. Paarhufer und Unpaarhufer. VEB Gustaw Fischer Verlag: 1-939. Jena.

4 The opinion is expressed in the paper by Jezierski \& Myrcha (1975) that permissible density of a wild boar population in forests with good food supply and variety of habitats may be as much as 20 individuals per 1000 ha of forest. The authors' original opinion that density should not be lower than 20 individuals per 1000 ha of forest was distorted during translation of the text. 
15. He y manowski K., 1966. Dzieje Puszczy Kampinoskiej do polowy XIX wieku. Sylwan, 110: 1-15.

16. Jezierski W., 1977: Longevity and mortality rate in a population of wild boar. Acta theriol., 22, 24: 337-348.

17. Jezierski W., 1972: Gospodarcze znaczenie szkód łowieckich wyrządzanych przez dziki., Łowiec pol., (1421): 1-2.

18. Jezierski W., 1976: Zastosowanie teorii populacji w łowiectwie. Państw. Wyd. Nauk.: 1-119. Warszawa.

19. Jezierski W., \& Myrcha A., 1975: Food requirements of a wild boar population. [In: "The role of large herbivore mammals in woodland ecosystems ", Ed. W. Grodziński, Z. Pucek]. Pol. ecol. Studies, 1, 2: 61-83.

20. Koehler W., 1954: Perspektywy wykorzystania dzika w ramach metody biologicznej. Roczn. Nauk Leś., 4 (111): 125-140.

21. Krebs Ch.J., Keller B.L. \& Tamarin R. H., 1969: Microtus population biology: changes in fluctuating populations of $M$. ochrogaster and $M$. pennsylvanicus in Southern Indiana. Ecology 50, 4: 587-607.

22. L e bedeva A., 1956: Ekologičeskije osobennosti kabana Beloveskoj Pušč. Uč. Zap. Moskovsk. Gorodsk. Ped. Instituta. 61: 105-271.

23. Lincke M., 1938: Der Wildschaden im Wald und Feld und die Mittel zu seiner Verminderung. J. Neumann Verlag: 1-370. Neudamm und Berlin.

24. M a ckin R., 1970: Dynamics of damage caused by wild boar to different agricultural crops. Acta theriol., 15, 27: 447-458.

25. M a u g t R., 1975: Observations sur la reproduction du sanglier (Sus scrofa 1.) a l'etat sauvage. An. Biol. anim. Bioch. Biophys. 12: 195-202.

26. Mats chke G. H., 1964: The influence of oak mast on European wild hog reproduction. Proc. XVIII ann. Conf. Southeast. Ass. Game and Fish Commissioners. Oct. 18-21: 1-5.

27. M r o z ow ski J., 1966: Rola dzika w ograniczaniu rozwoju strzygoni choinówki na terenie nadleśnictwa Goląbek w roku 1961/62. Sylwan 110: 63-70.

28. Myrcha A., \& Jezierski W., 1972: Metabolic rate during the postnatal development of wild boars. Acta theriol., 17, 33: 433-452.

29. Na u mov N.P. \& Nikolskij W. G., 1962: O nekotoryh obščh zakonomernostjah dinamiki populacji životnyh. Zool. Ž. 41: 1132-1139.

30. Ol of $f$ H. B., 1951: Zur Biologie und Oekologie des Wildschweines. Paul Schöps Verlag: 1-95. Frankfurt a. M.

31. Petrusewicz K., 1958: Investigation of experimental induced population growth. Ekol. pol. A, 5, 9: 281-309.

32. Pet:. usewicz K., 1963: Population growth induced by disturbance in the ecological structure of the population. Ekol. pol. A, 11, 3: 88-125.

33. Petrusewicz K. \& Andrzejewski R., 1962: Natural history of a freeliving population of house mice (Mus musculus Linnee us) with particular reference to groupings within the population. Ekol. pol. A., 10, 5· 85-122.

34. P i e l o w s i Z., 1966: Forschungen über den Feldhasen. XII. Die Raumstruktur der F'opulation. Acta theriol., 11, 22: 449-484.

35. Rall J., 1936: Harakter predviženij mysevidnyh gryzunov na nebolsyh plošcadah. Zool. Ž., 15, 3: 472-482.

36. Rörig H., 1912: Wild, Jagd und Bodenkultur. J. Naumann Verlag: 1-182 Neudamm.

37. Sylva-Ta rouca E., 1900: Hodowca a myśliwy. Łowiec pol.: 1-187. Warszawa. 
38. Traczyk H. \& Traczyk T., 1965: Charakterystyka fitosocjologiczna terenów badawczych Instytutu Ekologii PAN w Dziekanowie Leśnym (Puszcza Kampinoska) Frag. Flor. geobot., 11, 4: 547-562.

39. Wagenknecht E., 1962: Aus sechs Jahren Forschungsarbeit in Rotwildforschungsarbeit Hohenbucko. Beiträge zur Jagd-und Wildforschung, 2: $000-000$.

40. Wierzbowska T., 1971: Truncated distributions nad their application in ecology. Ekol. pol., 18, 40: 837-848.

\section{Roman ANDRZEJEWSKI \& Włodzimierz JEZIERSKI}

\section{WPEYW ZMIANY STRUKTURY WIEKOWEJ I DODATKOWEGO POKARMU NA DYNAMIKE LICZEBNOŚCI POPULACJI DZIKOW}

\section{Streszczenie}

W latach 1965-1970 na terenie około 2.500 ha lasów pólnocno-wschodniego krańca Puszczy Kampinoskiej i na przyległych do niej terenach polnych przeprowadzono badania mające na celu ocenę możliwości ograniczenia szkód powodowanych przez dziki w uprawach rolniczych przy pomocy działania na strukturę wiekową i sytuację troficzną populacji. Zastosowano odłowy dzików wg schematu CMR i obserwacje znakowanych zwierząt w porze szczytu aktywności żerowej. Przez likwidację części odławianych dzików regulowano strukturę wiekową celem zwiększenia udziału starszych klas wiekowych. Populacja dzików była stale dokarmiana atrakcyjną karmą, rejestrowano czas wykorzystania i ilości zjadanej karmy. Oceniano wielkość szkód powodowanych przez badaną populację w uprawach rolniczych w cyklu rocznym.

Obliczono, że dla badanej populacji i przyjętych założeń metodycznych (1 punkt odłowowy na około 300 ha powierzchni leśnej) odcinek czasu między kolejnymi zlowieniami dzika osiadłego nie może być dłuższy niż 6 miesięcy (Tabela 4). Na tej podstawie przy pomocy kalendarza złowień scharakteryzowano wszystkie osiadle dziki w populacji i stwierdzono, że liczba osobników przybywających (w wyniku rozrodu i imigracji) oraz ubywających (w wyniku emigracji i śmiertelności) jest bardzo duża i waha się $w$ zależności od fazy życia populacji w granicach: przybywanie od 51-113\%, a ubywanie od 37-94\% średniej rocznej liczebności populacji (Tabela 9). Oprócz dzików osiadłych w populacji wyróżniono także grupę dzików efemerycznych, nie lowiących się i na tyle krótko przebywających na terenie badań, że nie można ich było zaliczyć do grupy dzików osiadłych. Przy pomocy obserwacji bezpośrednich $\mathrm{z}$ ambon obserwacyjnych, ze stosunku dzików oznakowanych do nieoznakowanych, określono względną wielkość tej grupy. Wynosiła ona $22,7 \%$ oznakowanych zwierząt $w$ wieku powyżej jednego roku życia (w grupie zwierząt efemerycznych nie spotykano dzików w pierwszym roku życia). Na podstawie oceny wielkości obu grup zwierząt (osiadłych i efemerycznych) w populacji oszacowano, że łączna coroczna rotacja w populacji wynosi około od $150-200 \%$ jej średniej rocznej liczebności.

Stwierdzono, że cechą charakterystyczną badanej populacji była przewaga samic, stosunkowo nieznaczna w klasie wiekowej warchlaków i rosnąca w starszych klasach wiekowych (Tabela 5). Caloroczne podawania wysoko wartościowej karmy 
(owsa) w dawkach $0,7-1,0 \mathrm{~kg}$ dziennie na jednego przeciętnego osobnika w populacji (Tabela 13), spowodowało gwaltowny wzrost liczebności populacji w wyniku rozrodu $z$ akolo 30 do około 250 osobników na terenie badań (Tabela 2, fig. 3). Po osiągnięciu szczytu liczebności populacja ta ustabilizowała się na poziomie 50-70 osobników w wyniku stalego ubywania osobników starszych niż 1 rok.

Zmiany liczebności badanej populacji miały znikomy wpływ na rozmiar wyrządzanych szkód (Tabela 2, Fig. 7). Podstawowe znaczenie miała podawana w lesie karma, wykładana także w okresie powstawania $75 \%$ szkód (Tabela 14), to jest od maja do sierpnia (Tabela 15). Z uwagi na antagonistyczne stosunki międzyosobnicze i międzygrupowe $w$ populacjach dzika, istotne znaczenia dla rozmiaru szkód ma również struktura socjalna populacji w powiązaniu z ilością punktów dokarmiania. Ruchliwość zwierząt zwiększa się wraz ze wzrostem zagęszczenia populacji (Fig. 5, Tabela 2). 